\title{
Disclosure of non-audit services in annual reports and auditor independence: Evidence from Italy
}

Received (in revised form): 21 st July 2010

\section{Giuseppe lanniello}

$(\mathrm{PhD})$ is a full professor of Economia Aziendale (Accounting and Business Administration) at University of Tuscia, Viterbo (Italy), Faculty of Economics and Management. His research interest includes financial reporting, accounting communication, external auditing and accounting history.

\begin{abstract}
This article explores recent regulatory reforms in Italy and analyzes the first-time application of mandatory disclosure in annual reports of audit and non-audit fees. This information can convey to readers of financial statements an indication of auditor independence (in appearance). An empirical analysis is conducted on annual reports of 239 Italian listed companies for the year 2007. The main research objectives are as follows: (1) to provide a comprehensive description of the relative level of non-audit fees; and (2) to investigate the relation between nonaudit services (NAS) and the opinion expressed in the audit report. The evidence shows that the average ratio of non-audit fees (further assurance services, tax advisory services and other services) to total auditor remuneration is 0.24 . In particular, there are 38 companies (15.9 per cent) that paid their auditor more for NAS than for audit services; excluding further assurance services, there are 22 cases $(9.2$ per cent) with a ratio of non-audit fees that is higher than 0.50 . In our sample, we observed 231 unqualified opinions ( 96.7 per cent) and eight qualified opinions ( 3.3 per cent): a statistical significant relationship between the NAS ratio and qualified opinions was not found. However, the study's results show that there is a positive association between the emphasis of matter paragraph in the audit report and NAS. This finding cannot be interpreted as an indication of compromised auditor independence, thus opening space for further empirical studies on the use of emphasis of matter paragraphs in auditor reports.
\end{abstract}

International Journal of Disclosure and Governance (2010) 0, 000-000. doi:10.1057/jdg.2010.17

Keywords: auditor independence; non-audit services (NAS); disclosure; Italian listed companies; audit report

\section{INTRODUCTION}

Issues of compatibility of financial audit and the provision of management consulting to the same audit client are among the themes long

Correspondence: Giuseppe lanniello Faculty of Economics and Management, University of Tuscia - Viterbo, Via del Paradiso,

discussed regarding the effectiveness and role of

the statutory financial audit in modern society. In particular, this issue can be related to the analysis of auditor independence. On this topic, the theory and the praxis have offered several interpretations that are inevitably linked to the economic, social and cultural context. Mautz and Sharaf (1961, p. 247) proposed the distinction between 'apparent' and 'real' independence. The first trait concerns the public image of auditors as a professional group. The second one involves norms that individual auditors, as 